University of Wollongong

Research Online

Faculty of Social Sciences - Papers (Archive) Faculty of Arts, Social Sciences \& Humanities

$1-1-2015$

Participatory or deliberative democracy? Exploring the mediation effects of perceived online deliberation and online interactive activities on social outcomes

Kyung Han You

Pennsylvania State University

Jeong Kyu Lee

University of Wollongong, jklee@uow.edu.au

Hyunjin Kang

Pennsylvania State University

Eun Go

Pennsylvania State University

Follow this and additional works at: https://ro.uow.edu.au/sspapers

Part of the Education Commons, and the Social and Behavioral Sciences Commons

Research Online is the open access institutional repository for the University of Wollongong. For further information contact the UOW Library: research-pubs@uow.edu.au 


\title{
Participatory or deliberative democracy? Exploring the mediation effects of perceived online deliberation and online interactive activities on social outcomes
}

\author{
Abstract \\ Using the structural equation modeling method $(\mathrm{N}=811)$, this study explores the structural relationships \\ among online news consumption, political participation and social trust, with a focus on the mediating \\ effects of online users' deliberative perceptions and news-related online interactive activities. The \\ analysis confirms that users' perceptions of online deliberation exert a significant mediating effect on \\ users' levels of news consumption, political participation, and social trust. Users' interactive civic \\ messaging behaviors, on the other hand, solely enhance participatory intentions. The findings also show \\ that the consumption of political news and the consumption of entertainment news have different effects \\ on users' perceptions of online deliberation, social trust, and political participation. Specifically, while \\ political news has a direct and relatively strong influence on participation, entertainment news has a \\ limited and indirect effect on participation. Online interactive activities are negatively associated with \\ users' perceived competency for online deliberation. Further implications of the study are also discussed.

\section{Keywords} \\ outcomes, social, activities, interactive, participatory, deliberation, deliberative, online, perceived, effects, \\ mediation, exploring, democracy

\section{Disciplines} \\ Education | Social and Behavioral Sciences

\section{Publication Details} \\ You, K., Lee, J., Kang, H. \& Go, E. (2015). Participatory or deliberative democracy? Exploring the mediation \\ effects of perceived online deliberation and online interactive activities on social outcomes. Telematics \\ and Informatics, 32 (2), 205-214.
}


Seeking Democracy On The Web

\title{
Participatory or Deliberative Democracy?: Exploring the Mediation Effects of Perceived Online Deliberation and Online Interactive Activities on Social Outcomes
}

\begin{abstract}
Using the structural equation modeling method $(\mathrm{N}=811)$, this study explores the structural relationships among online news consumption, political participation and social trust, with a focus on the mediating effects of online users' deliberative perceptions and news-related online interactive activities. The analysis confirms that users' perceptions of online deliberation exert a significant mediating effect on users' levels of news consumption, political participation, and social trust. Users' interactive civic messaging behaviors, on the other hand, solely enhance participatory intentions. The findings also show that the consumption of political news and the consumption of entertainment news have different effects on users’ perceptions of online deliberation, social trust, and political participation. Specifically, while political news has a direct and relatively strong influence on participation, entertainment news has a limited and indirect effect on participation. In addition, online interactive activities are negatively associated with users’ perceived competency for online deliberation. Further implications of the study are also discussed.
\end{abstract}

Keywords: Political online news, Entertainment online news, Perceptions of online deliberation, Online interaction, Political participation, Social trust 
Seeking Democracy On The Web

\section{Introduction}

Over time, the Internet has become an important platform for the delivery of news. Indeed, a recent estimate (Pew Research Center, 2012) shows that online news consumption increased from $19 \%$ in 2000 to $46 \%$ in 2012 . The great popularity of online news consumption holds tremendous promise for political participation, given that the Internet offers an open digital space in which users are able to seek information and discuss current affairs like never before. Political communication scholars have sought to explore whether this changing media landscape influences news-consumption patterns as well as how online news consumption is associated with social outcomes such as political participation and social trust.

To explain such effects, some studies have focused on the role of the Internet as a public agora that can enrich deliberative perceptions, thereby contributing to society by fostering the democratic process (e.g., Dahlberg, 2001; Sunstein, 2001; Papacharissi, 2002). Other studies (e.g., Price \& Cappella, 2002; Shah et al., 2005; Quintelier \& Vissers, 2008) have focused on the degree to which the Internet offers opportunities for online news consumers to share ideas via diverse interactive technologies, therefore indirectly encouraging political participation. While the former of these studies attributes political participation to the deliberative perceptions facilitated by news consumption, the latter of these studies attributes participation to online interactive activities employing diverse technological features and that are engaged in either during or after reading online news. Given this, the present study attempts to investigate how deliberative perceptions and online interactive activities mediate the relationship between online news consumption and the social outcomes of political participation and social trust by developing a structural model.

In addition, in terms of online news consumption, the present study attempts to examine 
Seeking Democracy On The Web

the effects of different types of news consumption (political news and entertainment news) on civic engagement. Although many scholars have investigated the role of political news delivered online in influencing political participation and civic engagement (e.g., Shah et al, 2005), they have paid little attention to the relationship between entertainment news ("soft news") and civic engagement because it is generally assumed that entertainment news elicits irrational and emotional responses and therefore cannot foster deliberation. However, entertainment news also has the potential for increasing political knowledge and/or changing political attitudes, especially as shows such as The Daily Show and The Colbert Report have become popular among viewers. Nonetheless, we know very little about how the consumption of different kinds of news influences political participation. Thus, to address this gap in the literature, the present study considers two kinds of news_-political feature news and entertainment news.

All in all, the present study aims to achieve a comprehensive understanding of the relationships among two types of online news (political news and entertainment news), newsrelated online activities (deliberation perceptions and online interactive activities), online users' political engagement, and social trust by using a structural equation modeling (SEM) approach with a set of web-log data combined with survey questionnaires collected in South Korea.

\section{Literature Review}

\subsection{The effects of two types of online news consumption on political participation and social} trust

Ever since Putnam (1995) argued that television viewing has a negative effect on civic engagement, the question of whether media use negatively affects the formation of social networks or social activities has been debated among scholars (e.g., Lin, 2001; McLeod et al; 
Seeking Democracy On The Web

1999; Paxton, 1999, 2002). Scholars (e.g., Norris, 1996; Shah, 1998) who opposed Putnam argued that his study assessed television-watching behaviors by measuring the time spent watching TV without any consideration of either motivation or program preference. Williams (2006) noted that Putnam’s hypothesis also disregarded the distinctive features of the medium. Indeed, the consideration of distinctive features of certain media seems particularly important when explaining the role of the Internet in achieving social outcomes such as political participation and social trust. Unlike television, the Internet allows users to communicate and interact with each other, thereby sharing their ideas with others. This interactive trait is reinforced as the Internet merges with social networking services and mobile devices.

Among diverse online activities, online news consumption has garnered much scholarly attention. This is because news consumption behavior has been identified as a critical predictor for users’ political participation and social trust. For instance, Kaye and Johnson (2003) showed that online news consumption fosters political participation by making political information more accessible. Other studies have also indicated that getting news from the Internet increases users’ political interest (Livingstone \& Markham, 2008). In addition, many studies have reported a positive effect of the Internet or online news reading on social activity and civic engagement (Amadeo, 2007; Esser \& de Vreese, 2007; Franzen, 2000; Howard, Rainie, \& Jones, 2001; Norris, 2003; Robinson, Kestnbaum, Neustadtl, \& Alvarez, 2000). Finally, some studies (e.g., Weaver \& Drew, 2001; Norris, 2003) have found a significant association between informationseeking on the Internet and social trust.

However, such studies on the effects of online news consumption on social outcomes are somewhat limited, given that there is a lack of consideration for the broad range of content that Internet news provides. Different types of news content may have different effects on political 
Seeking Democracy On The Web

participation. Yet scholars have primarily focused on the effects of political news on political participation, viewing other types of news, particularly entertainment news, as "unhealthy” content. This is because entertainment news is said to either directly or indirectly undermine citizens’ willingness to engage in civic activities (e.g., Scheufele \& Nisbet, 2002; Shah et al., 2001).

However, as entertainment shows such as The Daily Show and The Colbert Report have become increasingly popular among viewers, the role of entertainment news in civic engagement has attracted scholarly attention as a means of political information gathering. Many studies (e.g., Baum, 2003; Brewer \& Cao, 2006; Prior, 2003; Young, 2004) demonstrated that entertainment programs fostered the ability of those who were not very politically attentive to engage in political learning, to evaluate political candidates, and/or to engage in political campaigns. In a similar vein, some studies supported the view that television entertainment such as political satires (e.g., The Daily Show, The Colbert Report) and late-night talk shows (e.g., The Tonight Show with Jay Leno, The Late Show with David Letterman) might be positively related to political participation (e.g., Hoffman \& Thomson, 2009; Tsfati et al., 2009), or at least not negatively associated with political participation (e.g., Cao \& Brewer, 2008). If this is indeed the case, it means that watching entertainment television does not necessarily lead to the mass apathy that inheres in a lack of civic engagement. Rather, it offers entertainment consumers, particularly adolescents, a way to reinvest in democratic citizenship.

Although entertainment news is becoming increasingly popular, its effect on political participation or social trust has yet to be clearly established. The present study, therefore, investigates the processes through which political news and entertainment news influence individuals' levels of political engagement and social trust by proposing the following research 
Seeking Democracy On The Web

question.

Research Question 1: Do different types of news content have different effects on social outcomes (political participation and social trust)?

\subsection{The effects of deliberation perceptions and online interactive activities}

In considering the reasons why online news consumption plays a significant role in increasing political participation and/or social trust, two perspectives can be postulated: 1) deliberation and 2) online interactive activities. First, online news consumption allows users to increase their political knowledge; this knowledge can then serve as a resource for political discussion as well as political decision-making (Kwak, Williams, Wang, \& Lee, 2005). Furthermore, users are able to be exposed to diverse, even conflicting, viewpoints on a given topic through their news consumption, thereby allowing the users to make rational decisions regarding the current issues. This process is called deliberation. In addition, online news consumption provides users a wide variety of opportunities to have political discussions, especially through diverse interactive tools such as discussion boards and blogs, which together create an online sphere suitable for political expression. Such interpersonal discussions and talks engaged in by users after reading online news are identified as a critical determinant in delivering social outcomes. Accordingly, the current study attempts to shed light on the mediating role of deliberation and online interactive activities in the association between online news consumption and its impact on political participation and social trust.

\subsubsection{The mediating role of deliberation}

Studies on deliberation are based on the idea that deliberation allows for a certain 


\section{Seeking Democracy On The Web}

intellectual flexibility—that is, the possibility of "changing one’s judgments, preferences, and views during the course of ... interactions” (Dryzek, 2000, p. 1). The process of deliberation is expected "to invoke substantive standards" based on which users can then "understand, revise, and resolve moral conflicts in politics” (Gutman \& Thomson, 2000, p. 161). Therefore, deliberation calls for the careful analysis of public affairs (Burkhalter at al., 2002; Dryzek, 2000; Fearon, 1998). In addition, and perhaps most critically, deliberation emphasizes respectful debate even in the face of disagreement, i.e., the open-minded and reciprocal process of solving problems (Abelson et al., 2003). Conflicts of opinion among persons who engage in deliberation may occur, yet deliberation emphasizes the need to respectfully consider others' opinions. This allows ordinary citizens to eventually reach more democratic decisions (Fearon, 1998).

In regard to the expected influence of online news consumption on deliberation, studies have shown inconsistent results. For instance, Sunstein (2001, p. 49) warned that the Internet could further polarize opinions because people would use it to make "echoes of their own voices and to wall themselves off from others.” Papacharissi $(2002,2004)$ also criticized the Internet for being characteristically exclusive and elitist—a far cry, in her opinion, from the openness often associated with it. She argued that online discussions tend not to give rise to rational debate, because online debaters tend to prefer to exchange opinions only with "like-minded" people. Such skeptical observations imply that online news consumption or discussions may cause audiences to fragment, which, in turn, hampers public deliberation on the web (Dahlberg, 2001).

Yet many scholars still hold out hope for the Internet as a potential sphere for deliberation. For example, Shah and her colleagues (2007) proposed an O-S-R-O-R (Orientations-Stimuli-Reasoning-Orientations-Responses) framework, an extension of the O-SO-R model, to explain the effects of news media use on individuals' political participation. In the 


\section{Seeking Democracy On The Web}

O-S-O-R process suggested by Markus and Zajonc (1985), O stands for orientation, which includes the cognitive and motivational traits individuals have, with these traits influencing the reception of messages. S stands for stimuli, and the second $\mathrm{O}$ means the orientation formed after stimuli are received. The R represents the subsequent response (McLeod et al., 1994). Inspired by this O-S-O-R framework, Shah et al. (2007) suggested a more sophisticated model by incorporating a second $\mathrm{R}$ (reasoning) between the $\mathrm{S}$ and the second $\mathrm{O}$ in order to account for the role of mental elaboration and the deliberative process. In other words, the effects of news media use on political participation are achieved by the way of a reasoning process (i.e., deliberation), which can also be referred to as mental elaboration and collective consideration of a given topic. This reasoning process is a critical step in yielding political outcomes (Eveland, 2004; Eveland \& Thomson, 2006).

Given the important role of deliberation in the association between news media use and political outcomes, studies (e.g., Kaye \& Johnson, 2003; Lee \& Kim, 2009; Kang et al., 2013) have sought to empirically demonstrate the effect of online news usage on perceptions of online deliberation. For example, Kang and colleagues (2013) found that in-depth online news reading is strongly associated with news readers' perceptions of online deliberation. This result indicates that online news-consuming behaviors allow users to opportunities to be exposed to the diverse opinions of others; in this way, the users are able to practice embracing and respecting others' opinions, and to engage in rational thinking based on such diverse opinions. These actions are at the core of deliberation.

Furthermore, in addition to the political participation that results from the deliberative process, studies have shown that deliberation or citizen discussion also contributes to increased social trust. For instance, a series of studies conducted by Price, Cappella and their colleagues 


\section{Seeking Democracy On The Web}

(Price \& Cappella 2002; Price et al. 2002, 2003) found that people who attended online discussions regarding political issues showed increased social trust compared to those who did not attend such discussions. Carpini (1997) likewise demonstrated that deliberative discussions led participants to have greater trust in their discussion participants and eventually fostered diverse forms of civic engagement.

Therefore, based on previous findings, it can be postulated that online news media usage leads to greater political participation and social trust via deliberation. Hence, the following hypothesis is suggested.

Hypothesis 1: Online news consumers' perceptions of deliberation mediate the association between online news consumption and (a) consumers' political participation and (b) trust in society.

\subsubsection{The mediating role of online interactive activities}

Technology-mediated communications have become a major part of individuals' lives in modern society, earning the attention of communications scholars. The extended communication mediation model proposed by Shah et al. (2007), for example, suggests that engaging in online interactive activities through interactive technologies (e.g., e-mail, instant messaging, blogs, chat room, and online discussion boards) has a great influence on one's political engagement because such activities permit users to express their own political opinions at minimal cost. More specifically, the study found a significant indirect effect of online news use on political participation via interactive political messaging.

Previous studies (e.g., Ellis, 2010, Kang, 2004; Lupia \& Philpot, 2005; Shah et al., 2001) have specifically investigated how diverse interactive online activities such as scrapping, blogging, and commenting increase the exchange of opinions on the Internet as well as 


\section{Seeking Democracy On The Web}

participation in political issues. The practices of visiting political websites for the purpose of gathering information (McLeod et al., 2001) and participating in online discussions were both found to boost users' civic participation (Price \& Cappella, 2002). Using a cross-sectional analysis, Shah and colleagues (2005) found that interactive online activities, such as web browsing and emailing, both of which are activities used to express opinions about specific issues, encourages civic participation. Likewise, Quintelier and Vissers (2008) pointed out that interactive online activities such as emailing political content, blogging about political issues, and engaging in online discussion groups, were positively associated with users' levels of actual political participation.

Furthermore, recent studies have supported the positive role of online interactive activities in promoting social trust, especially as social networking sites (SNSs) have been gaining in popularity. Social trust is built upon a feeling of connectedness and reciprocity (Valenzuela, Park, \& Kee, 2009), and such outcomes can be achieved through engaging in the diverse interactive online activities afforded by new media. For example, people are able to build reciprocal relationships with others by participating in discussions and sharing their ideas on online discussion boards. Blogging allows people to create and belong to wider social networks than they might otherwise, which, in turn, contributes to users' heightened sense of connectedness. This increases users' trust in people in their networks, but also in society writ large.

Therefore, based on the literature, the present study hypothesizes that online interactive activities, such as online discussions and news blogging, are structurally associated with political participation and social trust. Hence, the following hypothesis is suggested.

Hypothesis 2: Online news consumers' interactive activities on the web mediate the 
Seeking Democracy On The Web

association between online news consumption and (a) consumers' political participation and (b) trust in society.

\subsection{The association between deliberation and online interactive activities}

The present study proposes two different mechanisms for understanding why online news consumption leads to political participation. However, the aim of this study is not only parceling out the possible differences between the two mechanisms but also examining how these two mechanisms — the two mediators of deliberation and online messaging —interact with each other, given that it remains open to question whether online activities such as political discussion, blogging, and emailing political content are positively linked to public deliberation.

Regarding such relationships, Mutz (2006) argued that it is necessary to distinguish between deliberative democracy and participatory democracy. Deliberative democracy emphasizes the process of deliberation whereas participatory democracy stresses the participation in collective decision-making. In other words, deliberative democracy should rest on rational consensus (Habermas, 1984) through respectful debate. On the other hand, participatory democracy entails an equal chance and power for each individual to participate in decision-making (Gbikpi, 2005; Pateman, 1970). In short, as Citrone (2010) pointed out, participatory democracy embraces "the quantitative dimension of democracy" while deliberative democracy holds "the qualitative” dimension of it (p. 34). According to Mutz, although these two types of democracy are not mutually exclusive and both can contribute to making a healthy democracy, deliberative democracy can be achieved without participatory democracy and vice versa. That is, it is possible that engagement in online discussion and other participatory web behaviors might be promoted without genuine dissent or debate. It is also plausible that 


\section{Seeking Democracy On The Web}

observing others' opinions may not lead directly to participation in online political discussions.

Furthermore, many scholars are still skeptical about for the Internet's role in deliberative exchanges of diverse opinions, given that major motivations for using the Internet have been shown to be information-seeking, entertainment, or shopping (Wojciezak \& Mutz, 2009; Barber, Mattson, \& Peterson, 1997).

Yet it is equally likely that online interactive activities, such as participating in online political discussions or blogging, can indeed promote deliberative idea exchanges or deliberative perceptions. Such activities provide users the opportunity to come face-to-face with dissimilar ideas, thereby allowing them to engage in deliberative thinking regarding certain political issues. Online discussions are particularly beneficial for deliberative thinking in that the online sphere permits active idea exchanges. By observing such active exchanges of political opinions, users are likely to perceive the online sphere as a site for negotiating ideas. Thus, based on the aforementioned discussion, the following research question is suggested:

Research Question 2: Is there a significant association between perceptions of deliberation and online interactive activities?

\section{Method}

\subsection{Participants}

The present study used web-log data combined with an online survey from the governmental report “New Paradigm of Journalism,” published by the Korea Information Society Development Institute (KISDI) in January 2008. ${ }^{1}$ In total, 811 participants, each of

\footnotetext{
${ }^{1}$ The present study used a set of web-log data combined with survey questionnaires. The set of data was collected b y Nielson-Korean Click, a leading web analysis corporation, which has approximately 40,000 panels. Web-log data,
} 


\section{Seeking Democracy On The Web}

whom accessed online news at least once a month, were selected for the analysis. The descriptive analysis of the demographics showed that $56.1 \%$ of the participants were male and $43.9 \%$ were female. 34.7\% of the participants were between the ages of 19 and 29; 36.9\% were in their 30s; and $28.3 \%$ were in their 40 s.

\subsection{Measures}

\subsubsection{Two types of online news usage}

You et al. (2013) divided online news usage into four types based on the assumption that users’ motivations differ according to the type of news being accessed. Kim et al. (2007) surveyed 33 online news sites and found that most sites offer eight standard news sections. Of these eight sections, two types of online news were selected for the present study: political news and entertainment news. The study used the same 33 websites referenced by Kim et al. (2007) and You et al. (2013) in order to collect log data. These two types of news use (time) were then converted into natural logarithm values in order to create a normal curve (for Entertainment news, $\mathrm{M}=5.65$, $\mathrm{SD}=2.51$; for Political news, $\mathrm{M}=2.51$, $\mathrm{SD}=2.93$ ).

\subsubsection{Perceptions of deliberation on the web}

Perceptions of online deliberation were measured on a 5-point scale ranging from 1 (not at all) to 5 (thoroughly), using the following five statements: "It is possible to make better decisions via discussions on the Internet”; "People are expect to achieve public opinion through using online news as well as taking part in online discussions”; "It is possible to understand public opinion via news reading and discussions on the Internet”; "News consumption and newsrelated activities such as blogging and discussions about public issues on the Internet can help to

which yield individuals' Internet-use records including page view and the time of usage, were collected from each pa rticipant's personal computer for the period of one month. And, data from the completed survey questionnaires were added to the dataset at the end of month. 


\section{Seeking Democracy On The Web}

resolve social conflict in our society”; and “Online debate can play an important role in forming public opinion” (Cronbach’s alpha $=.81, \mathrm{M}=3.46, \mathrm{SD}=.53)$.

\subsubsection{Online interactive activities}

The present study used web-log data of the time participants spent on Daum Agora, one of the most popular discussion websites in South Korea. Similarly, it used web-log data to measure news blogging in the context of the time users spent on Daum Blogger News, a filter blogging service offered by the Daum portal website. Users of Daum Blogger News leave their own opinions on certain issues raised in news articles on their Blog. The study determined the amount of time the participants spent both reading the website and engaging in activities such as linking and writing comments. The amount of time spent blogging and engaging in online discussions were treated similarly logarithmically (for News blogging, $M=1.48$, $S D=2.54$; for Online discussion, $\mathrm{M}=1.08, \mathrm{SD}=2.13$ ).

\subsubsection{Intentions for political participation}

Political participation was measured on a 5-point scale ranging from 1 (not at all) to 5 (thoroughly) using the following statements: "I will participate in a voluntary activity related to voting and a political campaign" and "I will vote in the upcoming presidential election." $(r=.54$, $\mathrm{M}=3.62, \mathrm{SD}=.95)$

\subsubsection{Social trust}

Four statements were used to measure social trust, again using a 5-point scale ranging from 1 (not at all) to 5 (thoroughly): "People expect to get rewards when trusting others"; "People in our country are credible”; “The rule of law works in our country”; and "It is beneficial to believe in people to start something in Korea” (Cronbach’s alpha $=.73, \mathrm{M}=2.94$, $\mathrm{SD}=.60)$ 
Seeking Democracy On The Web

\subsection{Model specification}

A structural equation modeling (SEM) analysis was implemented in order to test the hypothesized model using Mplus 5.2 (Muthen \& Muthen, 2007). All the parameters were estimated using the maximum likelihood (ML) estimation method. To evaluate the overall model fit, several fit indices were used (Hu \& Bentler, 1999), including the Chi-square of the estimated

model $\left(\chi^{2}\right)$, the root mean square error of approximation (RMSEA), the standardized root mean residual (SRMR), and the comparative fit index (CFI).

Online news type, online discussion/blogging, attitude to online deliberative discussion, and social trust were used as exogenous variables, while political participation was used as an endogenous variable. Online discussion/blogging, attitude to online deliberative discussion, and social trust were entered as mediators in the hypothesized model. To account for the effects of demographic characteristics such as gender, age, and education, the characteristics were entered in the hypothesized model as exogenous variables, from which pathways were drawn to all the endogenous variables.

To test the hypothesis regarding mediation effects, this study bootstrapped the indirect effects of online news consumption on political participation by repeatedly sampling cases with replacements from the data (i.e., 5,000 bootstrap sample draws). The bootstrap method is considered a useful way of alleviating statistical problems associated with non-normal distributions of indirect effects (Hayes, 2009; Preacher \& Hayes, 2008). The statistical significance of indirect effects was determined using 95\% biased-corrected confidence intervals (CI) estimated by the bootstrap method.

\section{Results}


Seeking Democracy On The Web

The hypothesized SEM model yielded a good fit to the data: $\chi^{2}(16)=23.58$; RMSEA $=.031(90 \% \mathrm{CI}=.008-.049) ; \mathrm{SRMR}=.018 ; \mathrm{CFI}=.967$. Most estimates in the model were in the expected direction; yet some estimates were not statistically significant.

Firstly, to answer RQ1, the study examined the direct effects of political news consumption and entertainment news consumption on political participation (PP) and trust in society (TS). Results indicated that only political news consumption directly affected users’ political participation $(\beta=.07, S E=.03, p=.013)$. Neither type of news consumption influenced social trust.

Secondly, in terms of the relationship among online news consumption, deliberation perceptions (both an individual's perception of online deliberation and the perception of user competency for online deliberation), and social outcomes (political participation and social trust), the path analysis showed significant associations between online news consumption and an individual's perception of online deliberation. In other words, both political news consumption and entertainment news consumption enhanced an individual's perception of the online deliberation achieved (PD) (for $\mathrm{PN} \rightarrow \mathrm{PD}, \beta=.04, \mathrm{SE}=.02, p=.007$ ). However, neither political news use nor entertainment news use was associated with the perception of user competency for online deliberation. In addition, it was found that only an individual's perception of the online deliberation achieved (PD) led to greater political participation $(\mathrm{PD} \rightarrow \mathrm{PP}, \beta=.53$, $S E=.08, p=.001$ ), while users’ perception of online deliberation (PD) was significantly related to trust in society (TS). Furthermore, trust in society turned out to affect political participation $(\mathrm{PP})($ for $\mathrm{PD} \rightarrow \mathrm{TS}, \beta=.11, \mathrm{SE}=.04, p=.039$; for $\mathrm{TS} \rightarrow \mathrm{PP}, \beta=.16, \mathrm{SE}=.05, p=.005$ ).

To test the mediating role of the two aspects of deliberation perception addressed in H1, a bootstrap test using 5,000 bootstrap resamples was performed. The bootstrap results showed that 


\section{Seeking Democracy On The Web}

political news consumption (PN) had an indirect effect on political participation (PP) through perceptions of online deliberation (PD): bootstrapped 95\% biased-corrected CIs for the effects of political news use via perception of online deliberation $(\mathrm{PN} \rightarrow \mathrm{PD} \rightarrow \mathrm{PP})=.001-.037$.

However, there was no indirect effect of online news consumption on social trust via deliberation perceptions. Thus, H1(a) was supported, whereas H1(b) was not.

Thirdly, regarding the relationships among online news consumption, online interactive activities (online discussion and news blogging) and social outcomes (political participation and social trust), the SEM analysis revealed that online news consumption had significant effects on news blogging and online discussion. More specifically, greater consumption of political news (PN) and entertainment news (EN) led to increased online discussion (OD) and news blogging $(\mathrm{NB})($ for $\mathrm{PN} \rightarrow \mathrm{OD}, \beta=.15, \mathrm{SE}=.07, p=.020$; for $\mathrm{EN} \rightarrow \mathrm{OD}, \beta=.08, S E=.03, p=.011$; for $\mathrm{PN} \rightarrow \mathrm{NB}, \beta=.18, \mathrm{SE}=.06, p=.007$; for $\mathrm{EN} \rightarrow \mathrm{NB}, \beta=.11, \mathrm{SE}=.04, p=.001)$. In addition, online discussion and news blogging each had a significant direct effect on political participation $($ for $\mathrm{OD} \rightarrow \mathrm{PP}, \beta=.05, \mathrm{SE}=.02, p=.002$; for $\mathrm{NB} \rightarrow \mathrm{PP}, \beta=.09, \mathrm{SE}=.03, p=.001)$. However, neither online discussion nor news blogging led to increased social trust.

Regarding the indirect effect of news consumption on social outcomes through online interactive activities as proposed in $\mathrm{H} 2$, the bootstrap results showed that political news consumption had an indirect effect on political participation by way of news blogging (PN $\rightarrow$ $\mathrm{NB} \rightarrow \mathrm{PP})=.003-.043$. In addition, the analysis showed that news blogging mediated the relationship between entertainment news consumption and political participation: bootstrapped 95\% biased-corrected CIs $(\mathrm{EN} \rightarrow \mathrm{NB} \rightarrow \mathrm{PP})=.003-.022$. However, there was no indirect effect of online news consumption on social trust via either online discussion or news blogging. Thus, while H2(a) is supported, H2(b) is not. 
Seeking Democracy On The Web

In terms of RQ2, which considers the association between online interactive activities and deliberation perceptions, the results showed that there was no association between users' engagement in online interactive activities and their perceptions of online deliberation

Finally, the demographic variables (gender, age, and income) introduced into the model were not significant predictors of political participation, as there was no statistical significance in the pathway to political participation. In regard to users’ political participation, all the predictors and intervening variables accounted for $15 \%$ of the variance. Table 1 presents the unstandardized parameter estimates and their standard errors in the SEM model (see Figure 1 for a visual summary).

\section{Discussion}

The present study explored the structural relations between two types of online news consumption (political news and entertainment news consumption) and social outcomes (political participation and social trust) using a SEM method. In particular, this study tested the effects of two mediators, deliberation perception and online interactive activities, on social trust and participation, postulating that the mediators would be associated with online news consumption, social trust, and political participation.

Firstly, the results of the present study support that online news use has a significant influence on participation, which is in accord with the findings of previous studies (e.g., Amadeo, 2007, Esser \& de Vreese, 2007, Norris, 2003). Moreover, based on previous research (e.g., Baum, 2003) showing the effect of entertainment news on civic engagement, the present study investigated the effects of different types of news—-political and entertainment—on social trust and political participation. The results show that the two types of online news differed 
Seeking Democracy On The Web

significantly in regard to their effects on political participation: while the consumption of political news was directly associated with individuals’ political participation, the consumption of entertainment news was not. However, another finding suggests that entertainment news use fosters deliberation perception on the Internet, and is positively associated with news blogging and online discussion. In particular, the consumption of entertainment news was shown to have an indirect effect on political participation via news blogging. From these findings, it can be concluded that, in contrast to many previous studies, entertainment news does have some effects on users’ levels of social trust and participation. Indeed, some recent studies (e.g., Baum \& Jones, 2012; Hoffman \& Thomson, 2009; Tsfati et al., 2009) have supported such an argument by showing that hybrid entertainment programs increase individuals' levels of trust in society and their political participation.

The study also found that an individual's perception of online deliberation was positively associated with social trust, and affected political participation either directly or indirectly. In particular, the perception of online deliberation was seen as a strong factor in predicting online news consumers' political participation. The analysis also showed that users' deliberation perceptions in regard to online public sphere had a significant mediating effect on political participation. That is, online news consumption was positively associated with users’ deliberation perceptions, thereby enhancing users’ political participation.

One interesting result was that interactive online activities had a contradictory effect on social trust and political participation. Specifically, news blogging and online discussion evinced no association with social trust, though these activities were shown to foster users' political participation. The reason for this may be explained by considering the specific cultural context of South Korea. While a high level of distrust in the government and political parties among Korean 


\section{Seeking Democracy On The Web}

citizens may motivate participation in online discussions, this same distrust might hamper political engagement. Indeed, Lee (1998) and Park (1999) argued that individuals in Korea were likely to distrust institutions even if they tended to participate in public issues; thus, the level of trust cannot be considered to correspond to the level of civic engagement. This suggests that an insignificant correlation between online activities and social trust does not necessarily translate to political cynicism, in that online activities were found to encourage users to engage in political affairs.

In addition, we can conclude that online discussion may either increase or decrease social trust depending on users' motivations for engaging in it, its ability to provide entertainment, and its ability to function as a means of exchanging information. When considering that entertainment news usage increases online discussion, we can infer that online discussion use is motivated by fun. Moreover, a previous study (Kim et al., 2005) noted that using the Internet for social or entertainment purposes decreased individuals' levels of social trust. Thus, our results call for a reconsideration of how and why individuals engage in discussion on the Internet.

Last, we found no association between deliberation perception and online interactive activities. Even though some previous research (e.g., Lee \& Kim, 2009) has shown that reading online discussions was positively associated with individuals' deliberative thoughts, our findings support Mutz's (2006) argument that engaging in online discussions and other participatory web behaviors can occur without the process of deliberation. However, our findings also indicated that individuals' consumption of online information enhanced their off-line political actions through both engaging in online interactive activities as well as perceiving online deliberation, which implies that online users engaged in political affairs in two different ways, but simultaneously. Given that some individuals participate in political affairs through deliberation 


\section{Seeking Democracy On The Web}

while others engage in offline political actions by participatory web activities, it is necessary to identify what determines an individual's pattern of political engagement. For example, individuals' personal characteristics such as need for cognition and competency for using online media might predict different pathways of political participation.

Although our findings have some significant implications, they also have some limitations. Firstly, the slightly-dated dataset may not accurately reflect current online users' behavior in the changing media environment, although the web-log data combined with survey data used in this study is still beneficial in studying structural relationships among online news consumption and individuals' civic engagement. It is probably necessary for future studies to continue to confirm the applicability of the perceptions of online public deliberation, particularly in other countries, as well as to explore how other psychological factors such as motivation and perception are associated with online news consumers' civic engagement.

Secondly, the current study considered only certain aspects of online news consumption. It is possible that the consumption of other news media might be coupled with the formation of individuals' deliberative attitudes in the online public sphere. To confirm this inference, it would be necessary for future studies to explore the impact of other media usage on shaping attitudes of this kind. 
Seeking Democracy On The Web

\section{References}

Abelson, J., Forest, P. G., Eyles, J., Smith, P., Martin, E., \& Gauvin, F. P. (2003). Deliberations about deliberative methods: Issues in the design and evaluation of public participation processes. Social Science \& Medicine, 57, 239-251.

Amadeo, J. (2007). Patterns of Internet use and political engagement among youth. In P. Dahlgren (Ed.), Young citizens and new media: Learning for democratic participation (pp. 125-146). New York, NY: Routledge.

Baum, M. (2002). Rocking the vote: What happens when presidential candidates hit the talk show circuit? Paper presented at the Annual Meeting of the American Political Science Association, Boston, MA.

Baum, M. (2003). Soft news and political knowledge: Evidence of absence or absence of evidence. Political Communication, 20, 173-190.

Bimber, B. (1999). The Internet and citizen communication with government: Does the medium matter? Political communication with government: Does the medium matter? Political Communication, 16, 409-428.

Bimber, B. (2001). Information and political engagement in America: The search for effects of information technology at the individual level. Political Research Quarterly, 54(1), 53-67.

Burkhalter, S., Gastil, J., \& Kelshow, T. (2002). A conceptual definition and theoretical model of public deliberation in small face-to-face groups. Communication Theory, 12, 398-422.

Cao, X., \& Brewer, P. (2008). Political comedy shows and public participation in politics. International Journal of Public Opinion Research, 20(1), 90-99.

Cappella, J. (2002). Does disagreement contribute to more deliberative opinion? Political Communication, 19(1), 195-112.

Chan, J., \& Leung, L. (2005). Lifestyles, reliance on traditional news media and online news adoption. New Media \& Society, 7(3), 357-382.

Coleman, J. (1990). Foundations of social theory. Cambridge, MA: Harvard University Press. 
Seeking Democracy On The Web

Dahlberg, L. (2001). Computer-mediated communication and the public sphere: A critical analysis. Journal of Computer-Mediated Communications, 7(1). Retrieved from http://jcmc.indiana.edu/vol7/issue1/dahlberg.html

Dahlgren, P. (2005). The Internet, public spheres, and political communication: Dispersion and deliberation. Political Communication, 22, 147-162.

De Vreese, C., \& Boomgaarden, H. (2006). News, political knowledge and participation: The differential effects of news media exposure on political knowledge and participation. Acta Politica, 41, 317-341.

Dryzek, J. S. (2000). Deliberative democracy and beyond. Oxford, UK: Oxford University Press.

Ellis, D. (2010). Online deliberative discourse and conflict resolution. Landscapes of Violence, 1(1). Retrieved from http://scholarworks.umass.edu/lov/vol1/iss1/6

Esser, F., \& De Vreese, C. (2007). Comparing young voters’ political engagement in the United States and Europe. American Behavioral Scientist, 50(9), 1195-1213.

Fearon, J. D. (1998). Deliberation as discussion, In J. Elster (Ed.), Deliberative Democracy (pp. 44-68). Cambridge: Cambridge University Press.

Gerbner, G., Gross, L., Morgan, M., Signorielli, N., \& Jackson-Beeck, M. (1979). The demonstration of power: Violence profile no. 10. Journal of Communication, 29(3), 177196.

Gerbner, G., Gross, L., Morgan, M., \& Signorielli, N. (1980). The mainstreaming of America: Violence profile no. 22. Journal of Communication, 30(3), 10-29.

Gibson, J. L., \& Bingham, R. D. (1982). On the conceptualization and measurment of political tolerance. American Political Science Review, 76, 603-620.

Gutmann, A., \& Thompson, D. (2000). Why deliberation is different. Social Philosophy and Policy, 17(1), 161-180.

Habermas, J. (1989). The structural transformation of the public sphere: An inquiry into a category of bourgeois society. Cambridge, MA: MIT Press.

Habermas, J. (2006). Political communication in media society: Does democracy still enjoy an epistemic dimension? The impact of normative theory on empirical research. Communication Theory, 16(), 411-426.

Hayes, A. F. (2009). Beyond Baron and Kenny: Statistical mediation analysis in the new 
Seeking Democracy On The Web

millennium. Communication Monograph, 76, 408-420.

Hoffman, L. H., \& Thomson, T. L. (2009). The effect of television viewing on adolescents' civic participation: Political efficacy as a mediating mechanism. Journal of Broadcasting \& Electronic Media, 53(1), 3-21.

Hu, L., \& Bentler, P. M. (1999). Cutoff criteria for fit indexes in covariance structure analysis: Conventional criteria versus new alternatives. Structural equation modeling, 6, 1-55.

Im, Y., Kim, K., \& Kim, Y. (2008). News perceptions and uses among online-news users. Korean Journal of Journalism \& Communications Studies, 52(4), 179-204.

Janssen, D., \& Kies, R. (2005). Online forums and deliberative democracy. Acta Politica, 40, 317-335.

Johnson, T., Bichard, S., \& Zhang, W. (2009). Communication communities or “CyberGhettos”? A path analysis model examining factors that explain selective exposure to blogs. Journal of Computer-Mediated Communication, 15, 60-82.

Kang, H., Lee, J., You, K., \& Lee, S. (2013). Does Online News Reading and Sharing Shape Perceptions of the Internet as a Place for Public Deliberations? Mass Communication \& Society, 16(4), 533-556.

Kang, N. (2004). Effect of Internet and mass media uses on citizens' participation: Generational differences. Korean Journal of Journalism \& Communications Studies, 48(3), 116-143.

Kaye, B., \& Johnson, T. (2003). From here to obscurity? Media substitution theory and traditional media in an on-line world. Journal of American Society for Information Science and Technology, 54(3), 260-273.

Kean, J. (2000). Structural transformations of the public sphere. In H. Kenneth \& J. van Dijk (Eds.), Digital democracy: Issues of theory and practice (pp. 70-89). London, UK: Sage.

Kenski, K., \& Stroud, N. (2006). Connections between Internet use and political efficacy, knowledge, and participation. Journal of Broadcasting \& Electronic Media, 50, 173-192.

Kim, E., Im, Y., Kim, K., \& Kim, Y. (2007). New paradigm of journalism. Seoul: Korea Information Society Development Institute Press.

Kim, E., Lee, J., \& Moon, T. (2005). The communicative foundation of social capital in Korea: Impacts of media uses on trust, civic engagement, and socio-political participation. Korean Journal of Journalism \& Communications Studies, 49(3), 234-261. 
Seeking Democracy On The Web

Kim, Y., \& Vishak, J. (2008). Just laugh! You don’t need to remember: The effects of entertainment media on political information acquisition and information processing in political judgment. Journal of Communication, 58, 338-360.

Kraut, R., Patterson, M., Lundmark, V., Kiesler, S., Mukopadhyay, T., \& Scherlis, W. (1998). Internet paradox: A social technology that reduces social involvement and psychological well-being? American Psychologist, 53, 1017-1031.

Krueger, B. (2002). Assessing the potential of Internet political participation in the United States. American Political Research, 30(5), 476-598.

Lee, J. (1998). Democracy, social trust, and social capital. Thought Quarterly (summer), 65-93.

Lee, Y., \& Kim, H. (2010, November 1). Two hours a day Internet use-forty minutes reading, more than an hour “online communicating.” Munhwa daily newspaper. Retrieved from http://www.munhwa.com/news/view.html?no=20101101010354270560020

Lee, J. \& Kim, E. (2009). Deliberation on the net: Lessons from a field experiment. In T. Davies \& S. P. Gangadharan (Eds.), Online deliberation: Design, research, and practice. CA: CSLI Publications.

Lin, N. (2001). Social capital: A theory of social structure and action. Cambridge, UK: Cambridge University Press.

Lin, C., Salwen, M., Garrison, B., \& Driscoll, P. (2005). Online news as a functional substitute for offline news In M. Salwen, B. Garrison, \& P. Driscoll (Eds), Online News and the public (pp. 221-236). Mahwah NJ: Lawrence Erlbaum.

Livingstone, S., \& Markham, T. (2008). The contribution of media consumption to civic participation. The British Journal of Sociology, 59(2), 351-371.

Lupia, A., \& Philpot, T. (2005). Views from inside the net: How websites affect young adults’ political interest. Journal of Politics, 67(4), 1122-1142.

Martin, P. (2008). The mass media as sentinel: Why bad news about issues is good news for participation. Political Communication, 25, 180-193.

Mattelart, A., \& Siegelaub, S. (Eds.) (1979). Communication and class struggle: Capitalism, imperialism (Vol. 1). New York, NY: International General. 
Seeking Democracy On The Web

McLeod, J. M., Scheufele, D. A., \& Moy, P. (1999). Community, communication, \& participation: The role of mass media and interpersonal discussion in local political participation. Political Communication, 16, 315-336.

McLeod, J. M., Zubric, J., Keum, H., Deshpande, S., \& Cho, J. (2001). Reflecting and connecting: Testing communication mediation model of civic participation. Paper presented at the Association for Education in Journalism and Mass Communication, Washington, DC.

Min, S. (2007). Online vs. face-to-face deliberation: Effects on civic engagement. Journal of Computer-Mediated Communication, 12(4). Retrieved from http://jcmc.indiana.edu/vol12/issue4/min.html

Min, Y., \& Joo, I. (2007). Social capital and its democratic consequences: Effects of media uses and social capital on political interest, trust, and participation. Korean Journal of Journalism \& Communications Studies, 51(6), 190-217.

Muthen, L. K., \& Muthen, B. O. (2007). Mplus user's guide. Los Angeles, CA: Muthen \& Muthen.

Mutz, D. (2006). Hearing the Other Side: Deliberative versus Participatory Democracy. New York, NY: Cambridge University Press.

Nguyen, A. (2003). The current status and potential development of online news consumption: A structural approach. First Monday, 8(9). Retrieved from http://firstmonday.org/issues/issue8_9/nguyen/index.html

Nie, N. H., Junn, J., \& Stehlik-Barry, K. (1996). Education and democratic citizenship in America. Chicago, IL: The University of Chicago Press.

Norris, P. (1996). Does television erode social capital? A reply to Putnam. Political Science and Politics, 29(3), 474-480.

Norris, P. (2003). Turned out voters? Media impact on campaign learning. Ethical Perspectives, 9(3), 200-221.

Norris, P., \& Jones, P. (1998). Virtual democracy. Harvard International Journal of Press Politics, 3(2), 1-4. 
Seeking Democracy On The Web

Papacharissi, Z. (2002). The virtual sphere: The Internet as a public sphere. New Media \& Society, 4, 9-27.

Papacharissi, Z. (2004). Democracy online: Civility, politeness and the democratic potential of online political discussion group. New Media \& Society, 6, 259-283.

Park, C. (1999). Social shock of economic crisis, crisis of trust and social capital. Societal Critics, 19, 33-64,

Patterson, T. (1994). Out of order: An incisive and boldly original critique of the news media’s domination of America's political process. New York, NY: Vintage Books.

Paxton, P. (1999). Is social capital declining in the United States? A multiple indicator assessment. The American Journal of Sociology, 105(1), 88-127.

Paxton, P. (2002). Social capital and democracy: An interdependent relationship. American Sociological Review, 67(2), 254-277.

Pew Research Center (20012). News Consumption Survey. Retrieved from http://www.pewinternet.org/

Polat, R. (2005). The Internet and political participation: Exploring the explanatory links. European Journal of Communication, 20(4), 435-459.

Preacher, K. J., \& Hayes, A. F. (2008). Contemporary approach to assessing mediation in communication research. In A. F. Hayes, M. D. Slater, \& L. B. Snyder (Eds.), The Sage source book of advanced data analysis methods for communication research (pp. 13-54). Thousand Oaks, CA: Sage.

Price, V., \& Cappella, J. (2002). Online deliberation and its influence: The electronic dialogue project in campaign 2000. IT \& Society, 1(1), 303-329.

Price, V., Cappella, J. N., \& Nir, L. (2002). Does disagreement contribute to more deliberative opinion?. Political Communication, 19(1), 95-112.

Price, V., Goldthwaite, D., Cappella, J. N., \& Romantan, A. (2003). Online discussion, civic engagement, and social trust. In 2nd Annual Pre-APSA Conference on Political Communication, Conference on Mass Communication and Civil Engagement, Georgetown [Electronic Document: http://cct. georgetown. edu/apsa/papers/Price. pdf].

Putnam, R. (1995). Bowling alone: America’s declining in social capital. Journal of Democracy, 6(1), 65-78. 
Seeking Democracy On The Web

Putnam, R., Pharr, S., \& Dalton, R. (2000). Introduction: What's troubling the trilateral democracies? In S. Pharrand \& R. D. Putnam (Eds.), Disaffected democracies: What's troubling the traditional countries? (pp. 3-27). Princeton, NJ: Princeton University.

Quintelier, E., \& Vissers, S. (2008). The effect of Internet use on political participation: An analysis of survey results for 16-year-olds in Belgium. Social Science Computer Review, 26(4), 411-427.

Sachs, H. (1995). Computer networks and the formation of public opinion: An ethnographic study. Media, Culture \& Society, 17, 81-99.

Scheufele, D., \& Nisbet, M. (2002). Being a citizen online: New opportunities and dead ends. Harvard International Journal of Press/Politics, 7(3), 55-75.

Shah, D. V. (1998). Civic engagement, interpersonal trust, and television use: An individuallevel assessment of social capital. Political Psychology, 19(3), 469-496.

Shah, D. V., McLeod, J., \& Yoon, S. (2001). Communication, contest, and community: An exploration of print, broadcast, and Internet influences. Communication Research, 28(4), 464-506.

Shah, D. V., Kwak, N., \& Holbert, L. (2001). “Connecting” and “disconnecting” with civic life: Patterns of Internet use and the production of social capital. Political Communication, 18, 141-162.

Shah, D. V., Cho, J., Eveland, W. J., \& Kwak, N. (2005). Information and expression in a digital age: Modeling Internet effects on civic participation. Communication Research, 32(5), 531-555.

Shah, D. V., Cho, J., Nah, S., Gotlieb, M. R., Hwang, H., Lee, N., Scholl, R. M., \& McLeod, D. M. (2007). Campaign ads, online messaging, and participation: Extending the communication mediation model. Journal of Communication, 57(4), 676-703.

Sullivan, J., Pierson, J. E., \& Marcus, G. E. (1982). Political tolerance and American democracy. Chicago: University of Chicago Press.

Sullivan, J. L. \& Transue, J. E. (1999). The psychological underpinnings of democracy: A selective review of research on political tolerance, interpersonal trust, and social capital. Annual Review of Psychology, 50, 625-650.

Sunstein, C. R. (2001). Republic.com. Princeton, NJ: Princeton University Press. 
Seeking Democracy On The Web

Tsfati, Y., Tukachinsky, R., \& Peri, Y. (2009). Exposure to news, political comedy, and entertainment talk shows: Concern about security and political mistrust. International Journal of Public Opinion Research, 21(4), 399-423.

Weaver, D., \& Drew, D. (2001). Voter learning and interest in the 2000 presidential election: Did the media matter? Journalism \& Mass Communication Quarterly, 78(4), 787-798.

Weber, L., Loumakis, A., \& Bergman, J. (2003). Who participates and why? An analysis of citizens on the Internet and the mass public. Social Science Computer Review, 21(26), 2642.

Wilhelm, A. (2000). Democracy in the Digital Age: Challenges to Political Life in Cyberspace. London: Routledge.

Xenos, M., \& Moy, P. (2007). Direct and differential effects of the Internet on political and civic engagement. Journal of Communication, 57, 704-718.

You, K. H., Lee, S. A., Lee, J. K., \& Kang, H. (2013). Why read online news? The structural relationships among motivations, behaviors, and consumption in South Korea. Information, Communication \& Society, 16(10), 1574-1595.

Zhang, W., \& Chia, S. C. (2006). The effects of mass media use and social capital on civic and political participation. Communication Studies, 57(3), 277-297. 
Seeking Democracy On The Web

Table 1

Robust Maximum-Likelihood (FIML) Parameter Estimates

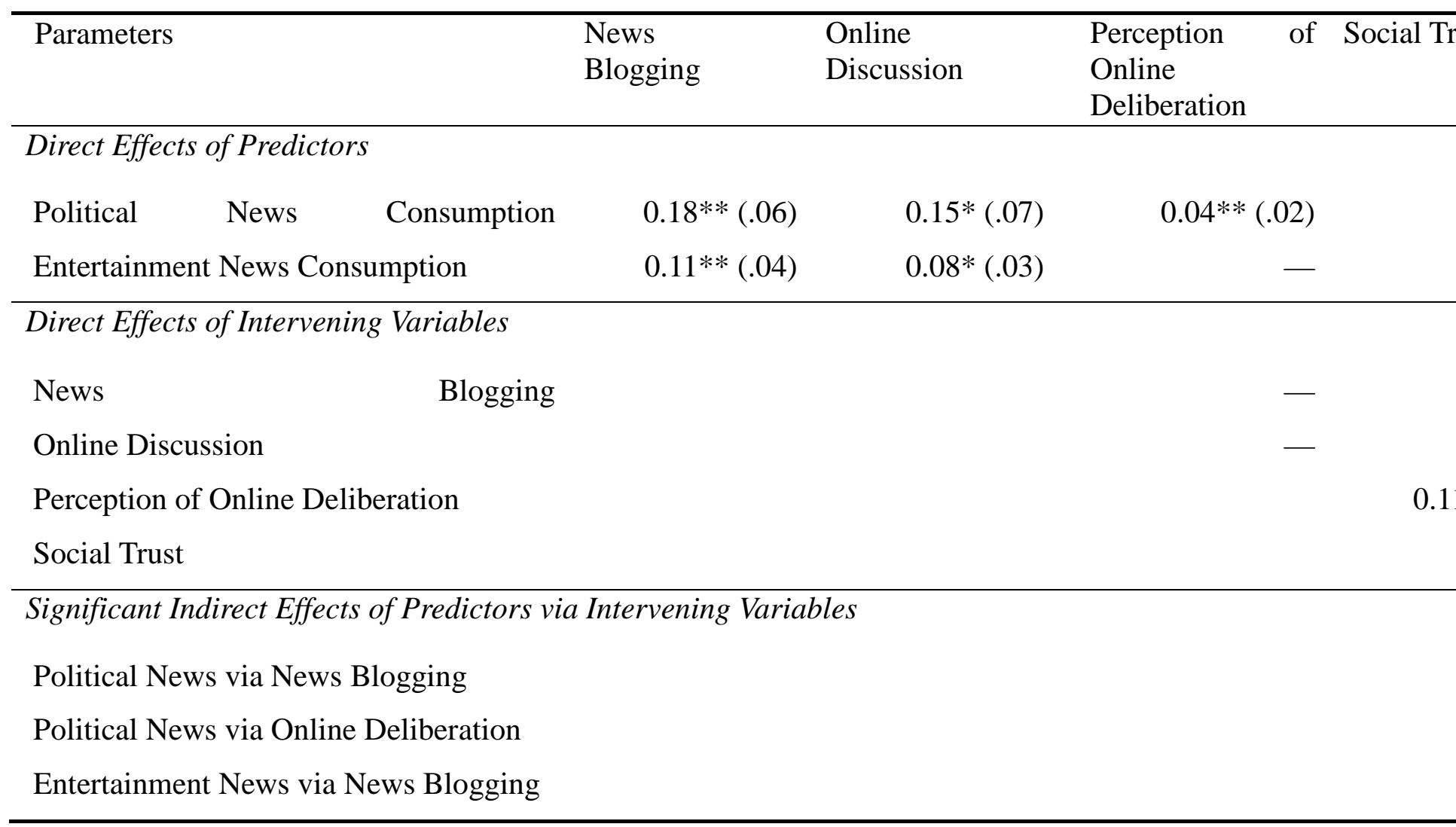

Note. 1) Path coefficients are unstandardized regression weights and the numbers in the parentheses are their standard errors. Dashes in the top panel indicate non-significant pathways.

2) Demographic (gender, age, and income) introduced to the model as control variables were not included in the table, as there was no statistical significance in the pathway to political participation.

$* p<.05, * * p<.01$. 


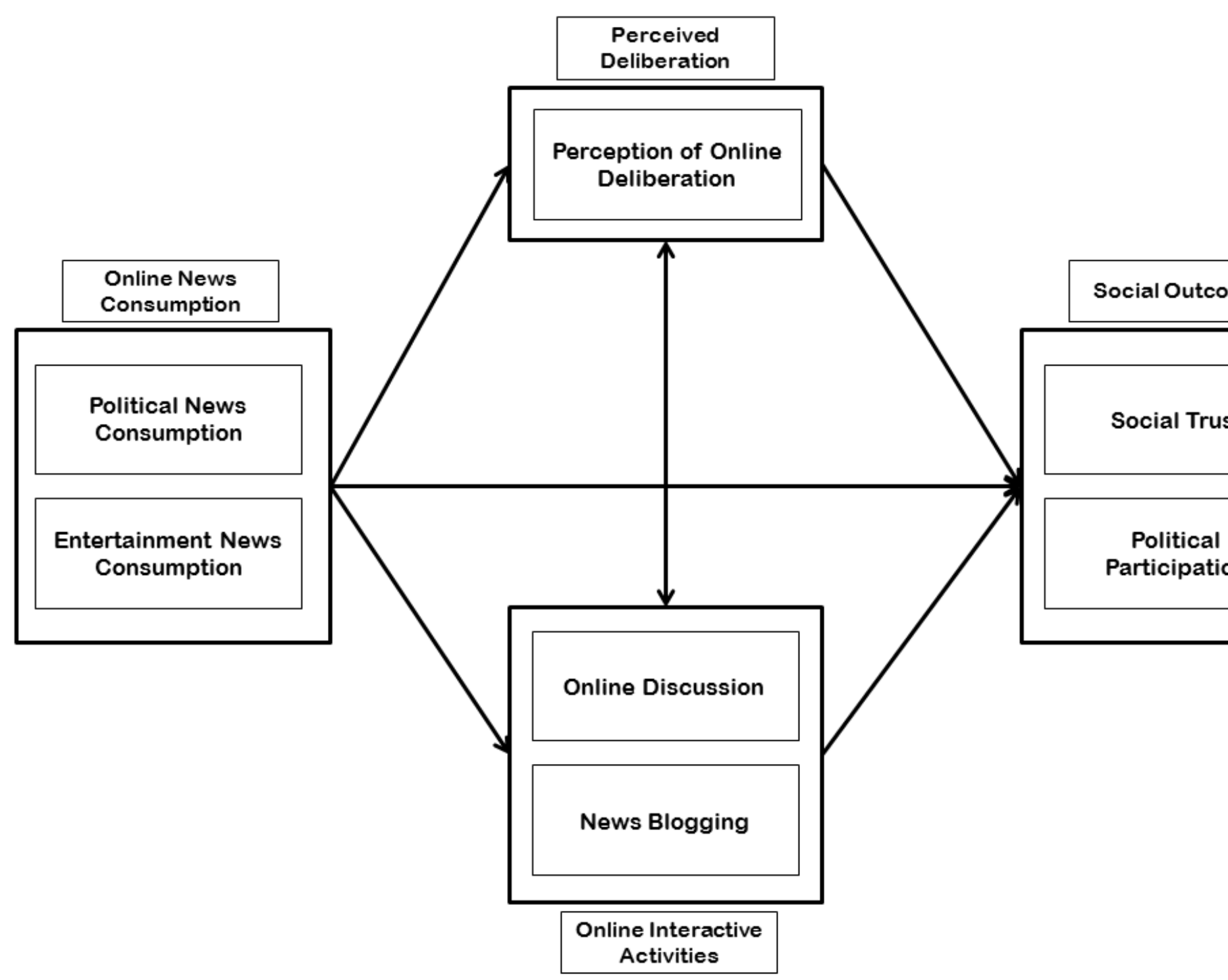

Figure 1. Model Suggestion 


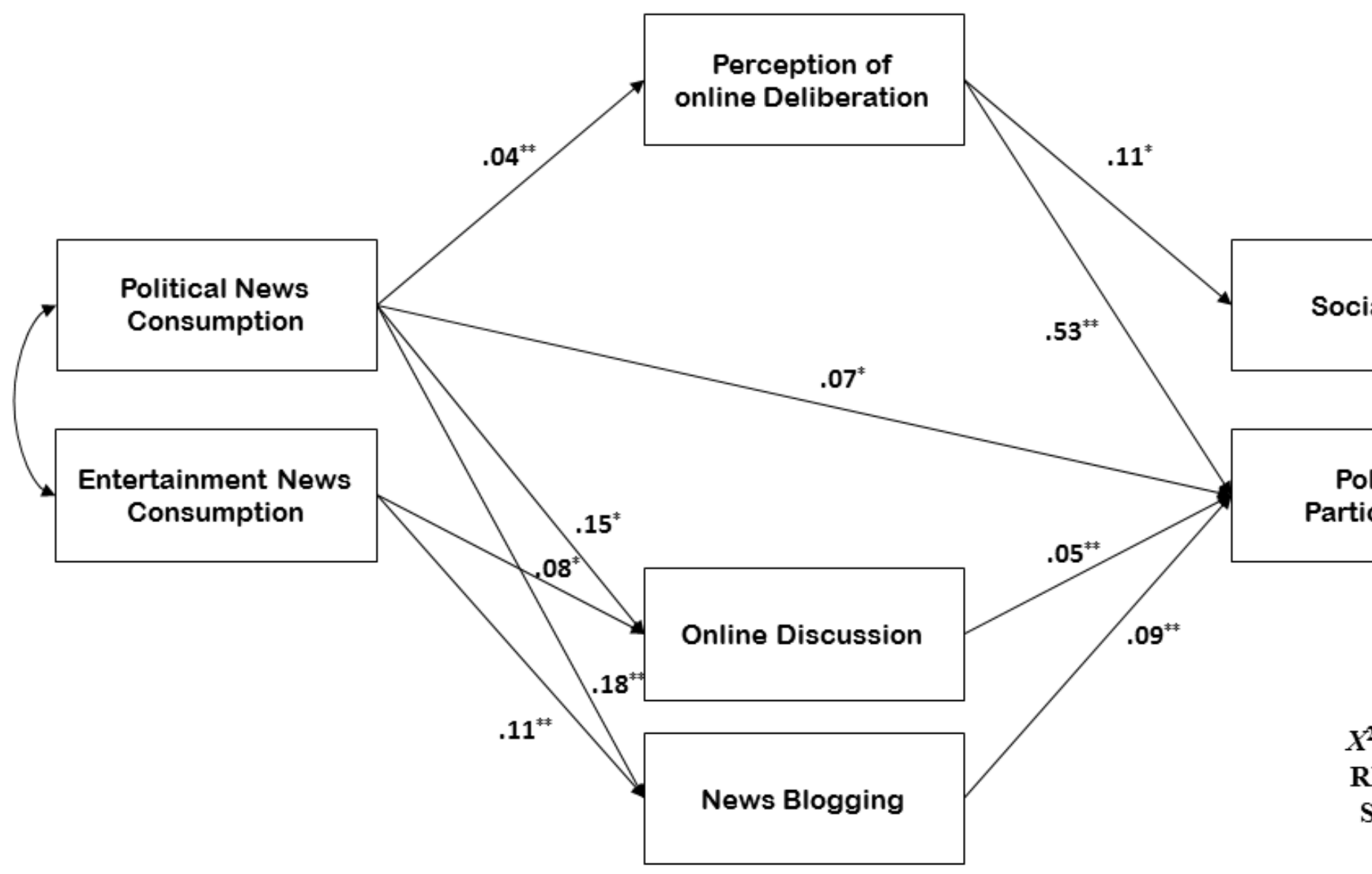

Note. Path coefficients in the figure are unstandardized, and only significant pathways are presented. The effects of gender, age, and education were controlled, but the pathways drawn from the control variables are not shown for clarity purposes.

$* \mathrm{p}, 0.05 ; * * \mathrm{p}, 0.01$.

Figure 2. Final path model. 